Published December 2019

EKONOMIKAWAN : Jurnal IImu Ekonomi dan Studi Pembangunan

ISSN : 1693-7600 (Print), ISSN : 2598-0157 (Online), http://jurnal.umsu.ac.id/indexphp/ekawan

\title{
Edukasi Penggunaan Internet Sehat, Aman dan Produktif Melalui Kelompok Majelis Taklim
}

\author{
Nori Wilantika $^{1^{*}}$, Mieke Nurmalasari ${ }^{2}$, Septian Bagus Wibisono ${ }^{3}$ \\ ${ }^{1}$ Program Studi Komputasi Statistik, Politeknik Statistika STIS, Jakarta, Indonesia \\ Jl. Otto Iskandardinata No.64C Jakarta Timur, DKI Jakarta 13330 \\ ${ }^{2}$ Universitas Esa Unggul, Jakarta, Indonesia \\ Jl. Arjuna Utara No.9 Jakarta Barat, DKI Jakarta 11510 \\ ${ }^{3}$ Pranata Komputer, Badan Meteorologi, Klimatologi, dan Geofisika, Jakarta, Indonesia \\ Jl. Angkasa 1 No.2 Jakarta Pusat, DKI Jakarta 10610 \\ *e-mail : wilantika@stis.ac.id
}

\begin{abstract}
ABSTRAK
Penggunaan internet selain membawa dampak positif kepada masyarakat, juga dapat memberikan dampak buruk melalui konten-konten negatif. Selain itu terdapat berbagai jenis kejahatan melalui internet yang mengancam keselematan penggunanya. Masyarakat perlu diberikan pengetahuan agar dapat melindungi diri dan keluarga dari pengaruh konten negatif dan dari ancaman kejahatan melalui internet. Aplikasi-aplikasi yang bermanfaat juga perlu diperkenalkan kepada masyarakat agar mengasilan sesuatu dari penggunaan internet. Edukasi penggunaan internet secara sehat, aman, dan produktif dimulai dari kelompok majelis taklim di daerah Jakarta Barat. Dari jumlah peserta yang hadir dapat dilihat bahwa kegiatan dapat diterima dengan baik oleh kelompok majelis taklim. Dari sesi tanya jawab terlihat bahwa materi yang disampaikan dapat dipahami dengan baik oleh peserta yang hadir. Kegiatan edukasi penggunaan internet serupa diharapkan dapat dilakukan secara berkelanjutan di majelis-majelis taklim lain.
\end{abstract}

Kata kunci: Edukasi Internet, Literasi Digital, Internet Sehat, Internet Aman, Internet Produktif 


\title{
Education on the Use of Healthy, Safe and Productive Internet Through the Taklim Assembly Group
}

\begin{abstract}
Internet penetration not only brings good but also harm through negative content. There are many crimes as well through the internet that threaten the safety of its users. Society needs to be educated to protect themselves and their family from negative content and cybercrime. Useful applications are also introduced to produce something from internet use. Education on healthy, safe, and productive use of internet starts form one of taklim assembly groups in West Jakarta. The number of participants shows that this kind of activity was well accepted by taklim assembly groups. From the discussion session, it was seen that the material was well understood by the participants. Similar internet education activities should be sustainably conducted in other taklim assemblies.
\end{abstract}

Keywords: Internet Education, Digital Literacy, Health Internet, Safe Internet, Productive Internet

\section{PENDAHULUAN}

Pengguna internet di Indonesia terus meningkat dari tahun ke tahun. Survei APJII pada tahun 2017 menunjukkan sebanyak 143,26 juta jiwa atau 54,68\% dari total penduduk Indonesia telah menggunakan internet (Asosiasi Penyelenggara Jasa Internet Indonesia \& Teknopreneur Indonesia, 2017). Angka tersebut meningkat menjadi 171,17 juta jiwa atau 64,8\% pada tahun 2018 (Asosiasi Jasa Penyelenggara Internet \& Polling Indonesia, 2018). Penetrasi internet dalam kehidupan masyarakat membawa dampak positif. Masyarakat memanfaatkan internet untuk berkomunikasi, mengakses pelayanan publik, mencari informasi terkait pekerjaan, pendidikan, dan kesehatan, membantu proses jual beli serta transaksi perbankan (Asosiasi Penyelenggara Jasa Internet Indonesia \& Teknopreneur Indonesia, 2017)(Asosiasi Jasa Penyelenggara Internet \& Polling Indonesia, 2018).

Dibalik dampak positif penetrasi internet, ada banyak kejahatan yang mengintai para pengguna internet (dikenal juga dengan kejahatan siber). Kejahatan yang dimaksud antara lain pencurian identitas, penipuan, pelecehan (bullying), pornografi, kekerasan, hingga eksploitasi seksual (Syaripudin et al., 2017) (Triastuti, Adrianto, \& Nurul, 2017). Data Kaspersky Lab dan B2B International dalam (Tangkary et al., 2018) menunjukkan bahwa Indonesia termasuk ke dalam tiga besar negara dengan ancaman kejahatan siber tertinggi.

Ditemukan bahwa $26 \%$ konsumen e-commerce adalah target aksi kejahatan siber dan 48\% konsumen e-commerce adalah target penipuan melalui pencurian data sensitif dan data keuangan (Tangkary et al., 2018). Selain itu, 49\% pengguna internet mengaku pernah diejek atau dilecehkan di media sosial dan 55,9\% mengaku pernah mengalami konten porno muncul secara tiba-tiba saat sedang terhubung ke internet (Asosiasi Jasa Penyelenggara Internet \& Polling Indonesia, 2018). Data pada penelitian (Triastuti, Adrianto, \& Nurul, 2017) juga menunjukkan bahwa sepanjang tahun 2011-2014 KPAI melaporkan 932 kasus pornografi dan kejahatan siber yang menjadikan anak-anak sebagai target korban. 
Sebagai upaya mencegah masyarakat dari kejahatan-kejahatan yang bersumber dari penggunaan internet, edukasi tentang penggunaan internet secara bijak dan aman perlu diberikan kepada masyarakat. Puspitasari dan Ishii pada penelitiannya mengungkapkan pentingnya edukasi teknologi informasi agar penggunaan internet khususnya melalui smartphone memberikan manfaat untuk meningkatkan taraf hidup masyarakat (Puspitasari \& Ishii, 2016).

Dengan latar belakang itulah, dilakukan pengabdian masyarakat berupa edukasi penggunaan internet yang menekankan pada aspek sehat, aman, dan produktif. Kegiatan ini sejalan dengan program pemerintah untuk mengupayakan literasi digital di tengah masyarakat.

Sasaran dari kegiatan ini adalah kaum ibu melalui kelompok majelis taklim. Kaum ibu dipilih sebagai target dengan harapan selain meningkatkan pemahaman para ibu tentang penggunaan internet secara aman dan produktif, para ibu juga dapat mengedukasi keluarganya masing-masing dan dapat melindungi anak-anak mereka dari kejahatan di dunia maya. Terdapat beberapa kegiatan edukasi internet yang juga menyasar kaum ibu seperti yang dilakukan oleh (Endah, Kusumaningrum, \& Noranita, 2016) dan (Novianti \& Fatonah, 2018) yang melakukan kegiatan penyuluhan melalui kelompok PKK. Terdapat pula kegiatan yang dilakukan oleh (Irawan, Koesoema, Soegijoko, Riyani, \& Utama, 2018) yang memberikan edukasi teknologi informasi, finansial, dan nutrisi kepada kaum ibu melalui program bernama Bunda Cermat.

\section{KAJIAN TEORI \\ Internet Sehat, Aman, dan Produktif}

Menurut Kementerian Informasi dan Informatika (Kemenkominfo), internet sehat dan aman memiliki arti menggunakan internet secara beretika agar terhindar dari pengaruh konten negatif dan dari kejahatan siber (Kementerian KOMINFO, 2013). Informasi yang disampaikan secara beruntun dan berulang mengenai risiko penggunaan internet yang tidak aman terbukti meningkatkan kesadaran masyarakat terhadap penipuan berbasis online baik yang risiko tinggi maupun risiko rendah (Davinson \& Sillence, 2010). Kemenkominfo membuat beberapa program yang bertujuan untuk melawan penyebaran konten negatif dan mensosialisasikan penggunaan internet secara sehat dan aman. Daintaranya yang saat ini sedang berjalan yaitu INSAN (Internet Sehat dan Aman) dan Gerakan Nasional Literasi Digital SiBerkreasi.

Adapun penggunaan internet secara produktif menurut Puspitasari dan Ishii (2016) adalah memanfaatkan internet untuk memperoleh informasi yang dapat meningkat meningkatan kapasitas diri dan ilmu pengetahuan penggunanya. Saat ini, pengguna internet melalui telepon genggam lebih lebih banyak mengakses internet untuk hiburan daripada mencari informasi untuk menambah ilmu pengetahuan. Edukasi teknologi informasi menjadi penting untuk meningkatkan manfaat dari penggunaan internet (Puspitasari \& Ishii, 2016). 
Penggunaan internet terbukti dapat meningkatkan produktivitas di beberapa aspek seperti pada bidang manufaktur dan jasa (Sánchez, Rata, Duarte, \& Sandulli, 2006) hingga di bidang agrikultur, di mana internet dimanfaatkan untuk memantau proses pertanian seperti kadar air dalam tanah, serangan hama, hingga pertumbuhan tanaman (Sreekantha \& Kavya, 2017).

\section{Majelis Taklim}

Majelis Taklim merupakan lembaga pendidikan agama islam yang bersifat nonformal dan memiliki fungsi untuk meningkatkan keimanan dan ketakwaan kepada Allah SWT dan akhlak mulia bagi jamaahnya (Bariah, Hermawan, \& Nur, 2012). Majelis taklim memiliki kegiatan rutin dalam meningkatkan pendidikan islam bagi masyarakat seperti kegiatan ceramah agama dan kegiatan belajar baca tulis Al-Quran (Amin, Marjuni, \& Azharia, 2018). Majelis taklim juga merupakan wadah silaturahmi bagi umat islam dalam bentuk penyelenggaraan kegiatan-kegiatan yang bersifat sosial keagamaan seperti mengunjungi panti asuhan dan kaum duafa, menghadiri acara pernikahan, mengunjungi warga yang sakit atau meninggal, dan buka puasa bersama pada Bulan Ramadhan (Amin, Marjuni, \& Azharia, 2018).

\section{METODE}

Pengabdian masyarakat ini dilakukan pada 24 Maret 2019. Edukasi penggunaan internet kepada kelompok Majelis Taklim Masjid Al Ikhlas dilakukan dalam bentuk sosialisasi kepada anggota yang hadir di Masjid Al Ikhlas RW 06 Kav. PTB, Tegal Alur Kalideres, Jakarta Barat. Materi mengenai internet sehat dan produktif dipaparkan kepada peserta selama kurang lebih satu jam. Sebagian besar materi dikutip dari seri buku literasi digital yang diluncurkan oleh Gerakan Nasional Literasi Digital Siberkreasi. Materi yang memerlukan praktikum dapat langsung dicoba oleh peserta menggunakan telepon genggam masing-masing peserta. Paparan materi dilanjutkan dengan sesi tanya jawab.

\section{HASIL DAN PEMBAHASAN}

Kegiatan edukasi penggunaan internet ini dibuka dengan penyampaian kata sambutan dari Ketua Majelis Taklim Masjid Al Ikhlas. Peserta yang hadir berjumlah 13 orang. Jumlah peserta yang hadir seharusnya bisa lebih banyak lagi. Namun pada saat yang bersamaan terdapat warga yang meninggal sehingga sebagian anggota Majelis Taklim Masjid Al Ikhlas pergi takziah ke rumah warga yang meninggal tersebut.

Dari kuesioner yang disebarkan kepada peserta, diketahui bahwa usia peserta cukup beragam yaitu antara 15 hingga 53 tahun. Delapan orang peserta merupakan lulusan diploma atau sarjana, empat orang peserta adalah lulusan SMU, dan satu orang peserta merupakan lulusan SMP. Dari keempat belas peserta, hanya ada satu orang yang tidak memiliki smartphone. Peserta yang memiliki smartphone rata-rata menggunakan smartphonenya kurang dari 5 jam per hari. Para peserta pada umumnya menggunakan smartphone untuk mengakses media sosial seperti facebook, twitter, dan instagram; mengakses aplikasi percakapan seperti whatsapp dan line; serta mencari informasi mengenai pendidikan, kesehatan, dan hiburan. 
Published December 2019

EKONOMIKAWAN : Jurnal IImu Ekonomi dan Studi Pembangunan

ISSN : 1693-7600 (Print), ISSN : 2598-0157 (Online), http://jurnal.umsu.ac.id/indexphp/ekawan

Materi yang disampaikan kepada anggota majelis taklim dibagi menjadi lima bagian sebagai berikut :

\section{Konten Pornografi dan Kekerasan}

Menurut ICT Watch, internet merupakan salah satu sumber terbesar dari pornografi dan kekerasan. Sebagian besar pornografi dan kekerasan terselubung di dalam permainan, komik, dan kartun. Untuk itu orangtua perlu mencermati setiap aplikasi yang diunduh oleh anak. Saat akan mengunduh aplikasi, informasi mengenai aplikasi tersebut harus dibaca dengan seksama. Pada Google Play Store misalnya, tersedia informasi mengenai batasan umur yang diperbolehkan untuk mengakses aplikasi yang akan diunduh serta konten kekerasan yang terdapat di dalam aplikasi tersebut.

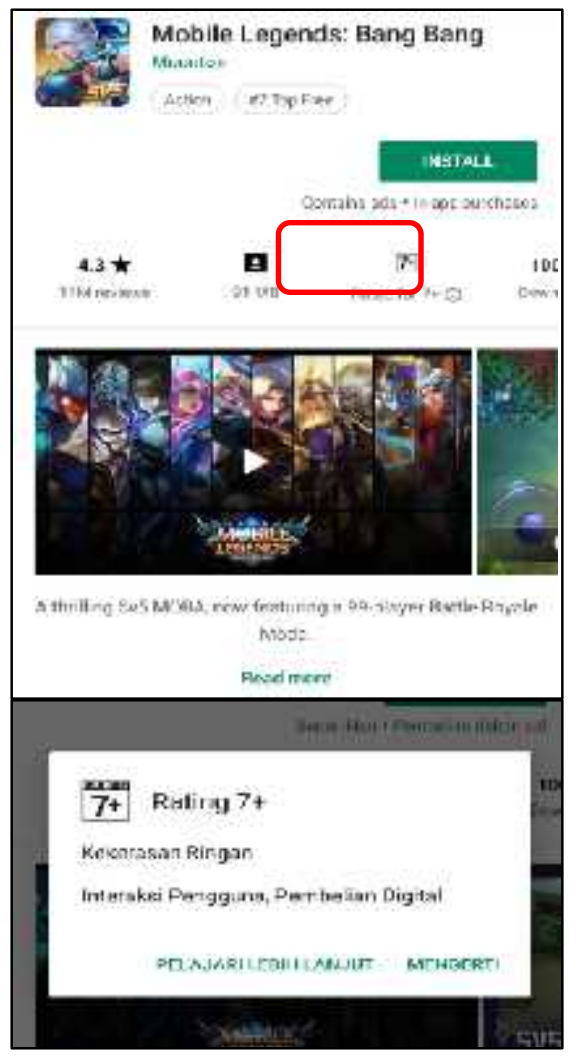

Gambar 1. Contoh Informasi Aplikasi Permainan pada Google Play Store

Gambar 1 menunjukkan contoh informasi sebuah aplikasi permainan. Aplikasi permainan tersebut adalah untuk pengguna berusia minimal 7 tahun. Di dalam permainan terdapat konten kekerasan ringan. Pengguna dapat membeli komponen permainan secara digital dan antar pemain juga dapat berinteraksi. Dengan bantuan informasi tersebut, orangtua dapat memutuskan dengan bijak untuk mengunduh aplikasi tersebut atau tidak.

Masih berkaitan dengan konten pornografi dan kekerasan, orangtua dapat mengawasi konten yang diakses oleh anak dengan bantuan aplikasi-aplikasi Parents Control seperti Quostudio, Monitory, Net Nanny, atau dengan mengeksplorasi fitur-fitur Parents Control yang sudah ada di pengaturan smartphone. 
Namun, pada dasarnya aplikasi-aplikasi tersebut hanyalah alat bantu. Kemendikbud dan Yayasan Kita Buah Hati menyebutkan bahwa hendaknya di dunia nyata orangtua betul-betul menjadi suri tauladan dengan pondasi agama yang kuat, bergaul dengan anak, dan memfasilitasi anak untuk menjalankan kegiatan-kegiatan dan hobi agar anak terhindar dari kondisi BLAST (Boring, Lonely, Angry, Stress, Tired). Kementerian Pendidikan dan Kebudayaan serta Yayasan Kita dan Buah Hati menyebutkan bahwa Anak dengan kondisi BLAST rentan menjadikan pornografi sebagai pelarian ${ }^{3}$.

Sebuah penelitian yang dilakukan pada sekelompok orangtua yang memiliki anak berusia 7 hingga 12 tahun menunjukkan para orangtua tersebut beranggapan bahwa internet masih lebih banyak memberikan dampak positif daripada dampak negatif ke anakanak mereka. Hasil penelitian tersebut juga menunjukkan bahwa para orangtua beranggapan masih dapat mengontrol penggunaan internet bagi anak-anak mereka (Shin, 2015). Anggapan tersebut nyatanya menyebabkan para orangtua menjadi kurang berkomunikasi secara mendalam dengan anaknya dan kurang memperbaharui pengetahuan mereka mengenai perkembangan internet.

\section{Penculikan}

Ada banyak sekali kasus penculikan yang bermula dari perkenalan di media sosial seperti yang ditunjukkan pada Gambar 2. Penculikan dapat terjadi dikarenakan anak tidak hati-hati dalam memilih teman (Triastuti, Adrianto, \& Nurul, 2017) atau anak mempublikasikan data pribadi pada media sosialnya (Syaripudin et al., 2017).

Untuk melindungi anak-anak dari penculikan, berikut adalah hal-hal yang dapat dilakukan oleh orangtua:

a. Bertemanlah dengan anak di media sosial tetapi tidak mengontrolnya (Tim Sejiwa, 2017).

b. Membiasakan anak untuk tidak gegabah menerima permintaan pertemanan di media sosial dikarenakan ada banyak orang yang suka menutupi identitas asli mereka dan menyamar sebagai orang lain.

c. Tegaskan kepada anak untuk tidak gegabah bertukar foto bahkan merencanakan pertemuan langsung dengan seseorang yang baru dikenal di media sosial. Jika anak bersikeras untuk tetap bertemu, maka harus dipastikan ada orang dewasa yang menemani dan pertemuan harus berlangsung di tempat umum (Syaripudin et al., 2017).

d. Orangtua dan anak harus berhati-hati membagikan informasi diri di media sosial khususnya informasi sensitif seperti alamat sekolah, alamat rumah, nomor telepon, dan tanggal lahir. 
Published December 2019

EKONOMIKAWAN : Jurnal IImu Ekonomi dan Studi Pembangunan

ISSN : 1693-7600 (Print), ISSN : 2598-0157 (Online), http://jurnal.umsu.ac.id/indexphp/kkawan

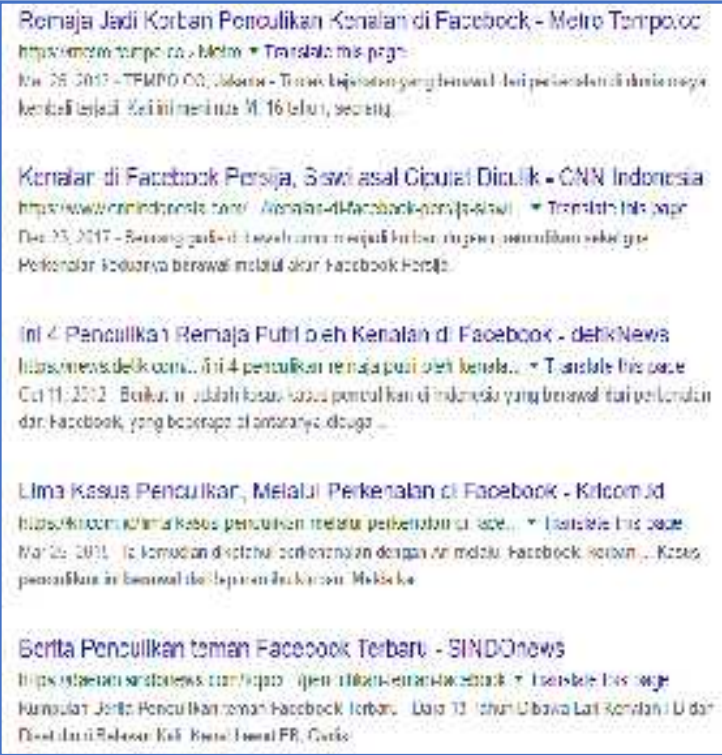

Gambar 2. Kasus-kasus Penculikan yang Bermula dari Perkenalan di Media Sosial

\section{Pemerasan dan Penipuan}

Pemerasan dan penipuan di dunia siber terjadi melalui spam dan phishing (Tangkary et al., 2018). Spam adalah surat elektronik (email) komersial yang dikirimkan secara massal dan tanpa diminta oleh penerimanya (White, 2011). Spam biasanya memuat virus atau malware yang dapat menguasai perangkat pengguna, memata-matai privasi pengguna, mengambil informasi pribadi pengguna, atau melakukan apapun sesuai dengan keinginan pembuat virus (Tangkary et al., 2018).

Sedangkan phishing adalah upaya pencurian informasi personal yang kemudian digunakan sebagai identitas palsu atau digunakan untuk pembelian barang secara ilegal. Informasi personal yang biasanya diincar adalah username dan password akun-akun pada situs jual beli, serta nomor kartu kredit (White, 2011). Pencurian informasi personal dilakukan melalui link yang diberikan lewat email atau melalui alamat website palsu yang dibuat serupa dengan email atau website perusahaan asli sehingga pengguna terjebak untuk memasukkan informasi personal.

Agar terhindar dari pemerasan dan penipuan, pengguna internet harus hati-hati dalam mengklik iklan, permainan, dan iming-iming diskon atau hadiah gratis. Tangkary et al. (2018) menyarankan untuk menghindari menggunakan Wi-Fi publik setiap melakukan transaksi online; selalu logout setelah selesai mengunjungi email, media sosial, situs belanja, internet banking, atau situs apapun yang mengandung data pribadi; serta berhatihatilah dalam membagikan informasi diri (Tangkary et al., 2018).

Dalam bertransaksi jual beli secara online, pengguna dapat menggunakan marketplace. Marketplace adalah website yang memfasilitasi penjualan dari banyak pedagang dan pembelian dari banyak pembeli (Tangkary et al., 2018). Mekanisme transaksi marketplace mengikuti standar protocol Secure Electronic Transaction sehingga transaksi cenderung lebih aman karena melibatkan banyak komponen (Sidharta \& Boy Suzanto, 2015). 


\section{Published December 2019}

EKONOMIKAWAN : Jurnal IImu Ekonomi dan Studi Pembangunan

ISSN : 1693-7600 (Print), ISSN : 2598-0157 (Online), http://jurnal.umsu.ac.id/indexphp/ekawan

Bila tidak berbelanja melalui marketplace, pengguna sebaiknya memeriksa terlebih dahulu rekening penjual sebelum melakukan transfer uang. Pengecekan dapat dilakukan menggunakan CekRekening.id. CekRekening.id merupakan situs resmi dari Kementerian KoKomunikasi dan Informatika yang berisi data-data rekening bank yang diduga terindikasi tindak pidana. Yang terpenting dalam bertransaksi jual beli secara online adalah jangan sungkan untuk meminta bantuan kepada anggota keluarga yang lebih mengerti tentang proses jual beli online.

\section{Berita Bohong}

Berita bohong atau biasa disebut hoax adalah berita yang berisi informasi yang tidak benar atau tidak terverifikasi kebenarannya (Adila, Weda, \& Tamitiadini, 2019). Dalam penelitian Aribowo (2017) disebutkan bahwa Hoax sengaja disebar untuk memicu kehebohan publik bahkan pertikaian di masyarakat seperti pembakaran vihara dan kelenteng yang terjadi di Tanjung Balai, Sumatera Utara pada Juli 2016 yang terjadi akibat hasutan melalui media sosial. Lalu ada pula peristiwa tawuran di Depok, Jawa Barat yang menewaskan dua orang karena dipicu oleh kabar bohong (Aribowo, 2017).

Pelaku penyebar hoax ada yang dengan sengaja menyebarkan hoax tersebut namun ada pula yang tidak sengaja dikarenakan tidak mengetahui bahwa berita yang disebarkan adalah hoax (Aribowo, 2017). Upaya yang paling ampuh untuk menekan penyebaran hoax, khususnya penyebaran yang terjadi secara tidak sengaja, adalah dengan memberikan edukasi agar masyarakat lebih melek media (Aribowo, 2017) (Adila, Weda, \& Tamitiadini, 2019). Melalui edukasi yang diberikan, masyarakat diharapkan memiliki pengetahuan untuk dapat memilah dan menyaring berita bohong yang tersebar di media digital.

Ciri-ciri berita bohong atau biasa disebut hoax adalah sebagai berikut (Aribowo, 2017) (Adila, Weda, \& Tamitiadini, 2019):

1. Judul mengandung unsur hasutan dan dibuat agar pembaca langsung menarik kesimpulan tanpa membaca isi berita.

2. Artikel dipenuhi huruf besar dan tanda baca yang berlebihan seperti titik dan tanda seru.

3. Mengandung kata-kata berunsur imperative sperti "Share", "Bagikan", "Sebarkan!!”, "Viralkan!!”, "Silakan berbagi”, "Beri tahu yang lain”, "Sebarkan ini ke semua orang yang Anda tahu, jika tidak, sesuatu yang tidak menyenangkan akan terjadi".

4. Merujuk ke kejadian dengan istilah kemarin, dua hari yang lalu, seminggu yang lalu, tanpa ada tanggal yang jelas.

5. Sumber tidak jelas misalnya "Sumber: dari lapak sebelah".

6. Link yang disertakan tidak dapat dibuka.

Untuk memastikan kebenaran informasi yang tersebar di media sosial, berikut hal-hal yang dapat dilakukan oleh pengguna internet:

1. Cari berita tersebut di situs pencarian seperti Google, menggunakan kata kunci diikuti dengan kata hoax.

2. Cek berita di forum-forum atau situs-situs anti hoax seperti Forum Anti Fitnah, Hasut, dan Hoax; turnbackhoax.id; hoaxbuster.id; dan hoaxornot.detik.com.

3. Gunakan aplikasi Hoax Buster Tools.

4. Bila tidak sempat mengecek berita yang diragukan kebenarannya, maka jangan sebarkan berita tersebut. 


\section{Published December 2019}

EKONOMIKAWAN : Jumal Ilmu Ekonomi dan Studi Pembangunan

ISSN : $1693-7600$ (Print), ISSN : 2598-0157 (Online), http://jurnal.umsu.ac.id/indexphplekawan

Sebagai bentuk perlawanan terhadap penyebaran hoax, pengguna internet dapat mengadukan hoax yang ditemukan di dunia maya dapat diadukan melalui aduankonten.id, trustpositif.kominfo.go.id, atau nawala.id. Ketiganya merupakan situs yang memfasilitasi aduan konten-konten negatif seperti hoax dan konten-konten yang mengandung pornografi dan kekerasan.

\section{Aplikasi Produktif untuk Perempuan}

Bila digunakan dengan bijak, internet dapat menghasilkan sesuatu bagi perempuan. Dengan internet, perempuan dapat mencari informasi yang bermanfaat untuk dirinya dan keluarga seperti masalah gizi, kesehatan, resep masakan, cara merawat anak, cara merawat diri, hingga menambah pengetahuan keagamaan. Perempuan dapat membentuk komunitas dengan perempuan-perempuan lain dengan hobi yang sama atau komunitas-komunitas sosial seperti komunitas peduli anak jalanan atau komunitas ibu-ibu pemerhati gizi. Internet juga dapat memfasilitasi perempuan untuk mengembangkan hobi dan berwirausaha lewat media sosial atau marketplace.

Beberapa aplikasi yang dapat digunakan oleh perempuan agar lebih produktif yaitu :

1. Aplikasi edukasi anak seperti Anak Cerdas Indonesia, Colors and Shapes for Kids, Pintar Cerdas Matematika, Endless Alphabet, dan Monkey Preschool Lunchbox.

2. Aplikasi memasak diantaranya Oh She Glows, BigOven, CookPad, Kitchen Stories, dan CookBok Recipes.

3. Aplikasi untuk membantu olahraga misalnya Calorie Counter, Runtastic Running App, dan Female Fitness.

4. Aplikasi untuk kesehatan wanita seperti aplikasi kalender menstruasi, aplikasi untuk memantau kesehatan ibu dan janin (Sehati dan TeleCTG), dan aplikasi untuk kesehatan reproduksi. Terdapat juga aplikasi untuk kesehatan keluarga seperti Instant Heart Rate, Alodokter, dan Mobile JKN.

Setelah semua materi disampaikan, peserta diberi kesempatan untuk bertanya bila ada materi yang belum dipahami. Pada sesi tanya jawab, peserta banyak bertanya mengenai aplikasi kesehatan. Kegiatan pengabdian masyarakat ini lalu diakhiri dengan penyampaian kata-kata penutup dari Ketua Majelis Taklim Masjid Al Ikhlas. Dokumentasi kegiatan dapat dilihat pada Gambar 3, 4, dan 5. Gambar 3 dan Gambar 4 menunjukkan suasana saat pemaparan materi. Gambar 5 adalah foto bersama seluruh peserta yang hadir pada kegiatan pengabdian masyarakat ini.

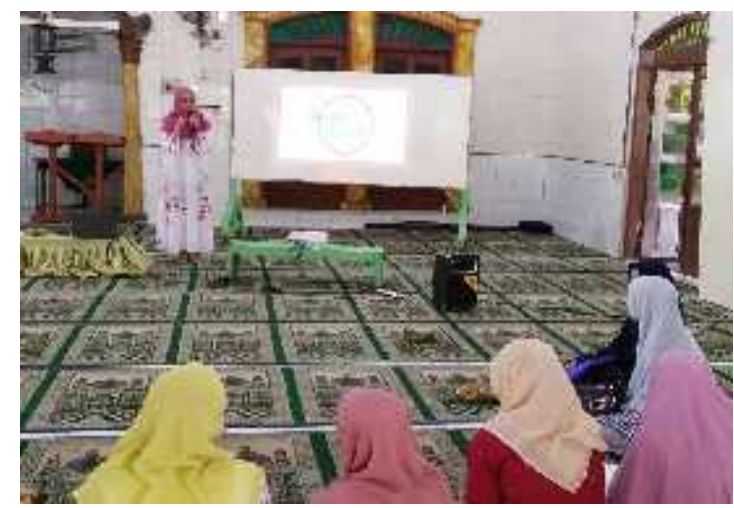

Gambar 3. Suasana Saat Pemaparan Materi Edukasi Internet Sehat, Aman, dan Produktif 


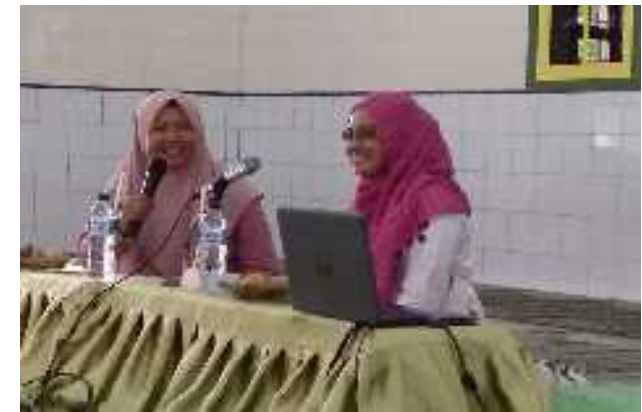

Gambar 4. Narasumber Edukasi Internet Sehat, Aman, dan Produktif

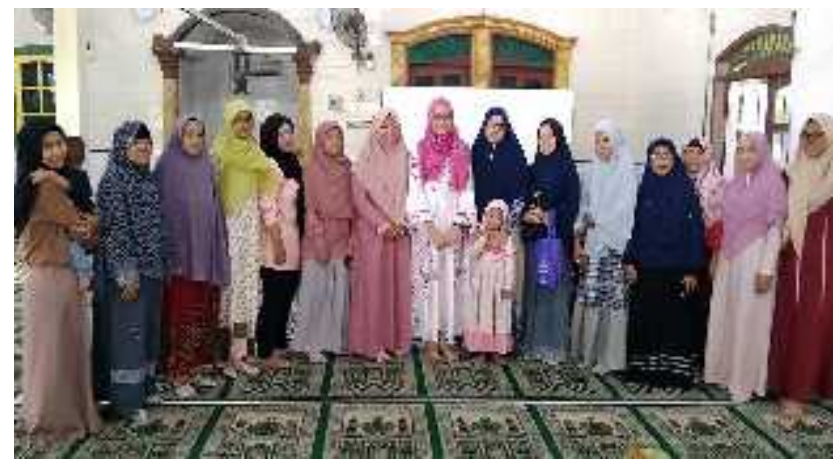

Gambar 5. Foto Bersama Peserta dan Narasumber

\section{SIMPULAN}

Kegiatan edukasi penggunaan internet dapat diterima dengan baik oleh Majelis Taklim Masjid Al Ikhlas. Hal ini merupakan sebuah awalan yang bagus untuk melakukan kegiatan serupa di majelis taklim-majelis taklim lainnya di seluruh Indonesia. Tantangan yang ditemukan dalam pelaksanaan edukasi internet ini adalah bagaimana agar materi yang dipaparkan tidak terlalu berat dan tidak terlalu teknis agar dapat dengan mudah dipahami oleh peserta tanpa mengurangi maksud yang ingin disampaikan. Perlu diperlukan penelitian lebih lanjut untuk melihat apakah pemahaman peserta terdapat penggunaan internet sehat, aman, dan produktif meningkat setelah diberikan edukasi.

\section{DAFTAR PUSTAKA}

Adila, I., Weda, W., \& Tamitiadini, D. (2019). Pengembangan Model Literasi Dan Informasi Berbasis Pancasila Dalam Menangkal Hoaks. WACANA, Jurnal Ilmiah Ilmu Komunikasi, 18(1), 101-111.

Amin, M., Marjuni, A., \& Azharia, D. (2018). Gerakan Sosial Keagamaan Masyarakat Perspektif Pendidikan Islam: Majelis Taklim Al-Mu'Minat. Jurnal Aqidah-Ta, 4(2), 149-159.

Aribowo, E. K. (2017). Menelusuri Jejak Hoaks Dari Kacamata Bahasa: Bagaimana Mendeteksi Berita Palsu Sedini Mungkin.

(2018). Laporan Survei Penetrasi \& Perilaku Pengguna Internet Indonesia 2018.

Asosiasi Jasa Penyelenggara Internet, \& Polling Indonesia. (2018). Laporan Survei Penetrasi \& Perilaku Pengguna Internet Indonesia 2018. 
Asosiasi Penyelenggara Jasa Internet Indonesia, \& Teknopreneur Indonesia. (2017). Infografis Penetrasi dan Perilaku Pengguna Internet Indonesia 2017.

Bariah, O., Hermawan, I., \& Nur, H. T. (2012). Peran Majelis Taklim Dalam Meningkatkan Ibadah Bagi Masyarakat di Desa Telukjambe Karawang. Solusi, 10(21), 1-10.

Davinson, N., \& Sillence, E. (2010). It won't happen to me: Promoting secure behaviour among internet users. Computers in Human Behavior, 26(6), 1739-1747. http://dx.doi.org/10.1016/j.chb.2010.06.023

Endah, S. N., Kusumaningrum, R., \& Noranita, B. (2016). Peningkatan Pengetahuan Internet Sehat dan Aman (INSAN) dalam Program Penyuluhan Berjenjang pada IbuIbu PKK di Kecamatan Tembalang. Makalah disajikan pada pertemuan Seminar Nasional Ilmu Komputer (SNIK 2016) (hal. 141-145). Semarang.

Irawan, Y. S., Koesoema, A. P., Soegijoko, S., Riyani, A., \& Utama, D. Q. (2018). Bunda Cermat: Integrating Financial, Nutrition and ICT Literacy for Women in Indonesia. Makalah disajikan pada pertemuan 2018 International Conference on ICT for Rural Development (IC-ICTRuDEv) (hal. 59-62). Badung Regency: IEEE.

Kementerian KOMINFO. (2013). Internet Sehat dan Aman (INSAN)1. 3 Juli 2019. https://kominfo.go.id/index.php/content/detail/3303/Internet-Sehat-dan-Aman-INSAN-/0/internet_sehat

Novianti, D., \& Fatonah, S. (2018). Literasi Media Digital di Lingkungan Ibu-Ibu Rumah Tangga di Yogyakarta. Jurnal Ilmu Komunikasi, 16(1), 1-14.

Puspitasari, L., \& Ishii, K. (2016). Digital divides and mobile Internet in Indonesia: Impact of smartphones. Telematics and Informatics, 33(2), 472-483. http://dx.doi.org/10.1016/j.tele.2015.11.001

Sánchez, J. I. L., Rata, B. M., Duarte, A. R., \& Sandulli, F. D. (2006). Is the Internet productive? A firm-level analysis. Technovation, 26(7), 821-826.

Shin, W. (2015). Parental socialization of children's Internet use: A qualitative approach. New Media and Society, 17(5), 649-665.

Sidharta, I., \& Boy Suzanto. (2015). Pengaruh Kepuasan Transaksi Online Shopping Dan Kepercayaan Konsumen Terhadap Sikap Serta Perilaku Konsumen Pada ECommerce. Jurnal Computech \& Bisnis, 9(1), 23-36.

Sreekantha, D. K., \& Kavya, A. M. (2017). Agricultural crop monitoring using IOT - A study. Makalah disajikan pada pertemuan Proceedings of 2017 11th International Conference on Intelligent Systems and Control, ISCO 2017 (hal. 134-139).

Syaripudin, A., Ahmad, D., Ningrum, D. W., Styawan, H., Ashar, I., Banyumurti, I., \& Indra, L. (2017). Internet Sehat; Pedoman Berinternet Aman, Nyaman, dan Bertanggungjawab. ICT Watch.

Tangkary, S., Hartono, H., Ameliah, R., Ahmad, D., Ningrum, D. W., Styawan, H., ... Zaenuddin. (2018). Keamanan Siber untuk e-Commerce. ICT Watch.

Tim Sejiwa. (2017). Digital Parenting: Menjadi Pendidik Unggul Bagi Millenial. Jakarta: Smart School Online.

Triastuti, E., Adrianto, D., \& Nurul, A. (2017). Kajian Dampak Penggunaan Media Sosial Bagi Anak Dan Remaja. Seri Literasi Digital.

White, C. M. (2011). Data Communications and Computer Networks: A Business User's Approach. Massachusetts: Course Technology. 